\title{
Prescription and Non-Prescription Drug Classification Systems Across Countries: Lessons Learned for Thailand
}

This article was published in the following Dove Press journal: Risk Management and Healthcare Policy

\author{
Doungporn Leelavanich (iD ${ }^{1}$ \\ Noppadon Adjimatera ${ }^{2,3}$ \\ Lawanworn \\ Broese Van Groenou ${ }^{4}$ \\ Puree Anantachoti ${ }^{1}$ \\ 'Department of Social and Administrative \\ Pharmacy, Faculty of Pharmaceutical \\ Sciences, Chulalongkorn University, \\ Bangkok, Thailand; ${ }^{2}$ Thailand Self \\ Medication Industry Association, \\ Bangkok, Thailand; ${ }^{3}$ Reckitt Benckiser \\ (Thailand) Ltd, Bangkok, Thailand; \\ ${ }^{4}$ DKSH (Thailand) Limited, Bangkok, \\ Thailand
}

\begin{abstract}
Purpose: The drug classification system, as prescription or non-prescription drug category, has been utilized as a regulatory strategy to ensure patient safety. In Thailand, the same system has been used for decades, though the drug classification criteria were updated to accommodate drug re-classification in 2016. These new criteria, however, have not been applied retroactively. Inconsistency in drug classification has been observed leading to concerns regarding the drug classification system. This has prompted the need for a review of the drug classification system in Thailand. This study aims to explore Thailand and other selected countries' regulatory management regarding the drug classification system, drug classification criteria, and drug classification itself.
\end{abstract}

Methods: The drug classification systems of the United States, the United Kingdom, Japan, Singapore, Malaysia, the Philippines, and Canada were selected to study alongside Thailand's system. The regulatory review was conducted through each country's drug regulatory agency website and available published research. Complementary interviews with drug regulatory authorities were conducted when written documentation was unclear and had limited access. Fifty-two common drugs were selected to compare their actual classifications across the different countries.

Results: All selected countries classified drugs into two major groups: prescription drugs and non-prescription drugs. The studied countries further sub-classified non-prescription drugs into 1-4 categories. Principles of drug classification criteria among countries are similar; they comprised of three themes: disease characteristics, drug safety profile, and other drug characteristics. Actual drug classification of antibiotics, dyslipidemia treatments, and hypertension treatments in Thailand are notedly different from other countries. Furthermore, $77.4 \%$ of drugs studied in Thailand fall into the behind-the-counter (dangerous) drug category, which varied from antihistamines to antibiotics, dyslipidemia treatments, and vaccines.

Conclusion: Thailand's drug classification criteria are comparable with other nations; however, there is a need to review drug classification statuses as many drugs have been classified into improper drug categories.

Keywords: drug category, classification criteria, prescription, non-prescription, OTC, drug regulatory

\section{Introduction}

Regulators around the world impose different restrictions on drug availability, such as prescription status, to protect the health. Different drug categories, such as prescription and over-the-counter drugs, lead to different drug access, channel of drug distribution, and permitted advertisement. ${ }^{1}$
Department of Social and Administrative

Pharmacy, Faculty of Pharmaceutica

Sciences, Chulalongkorn University,

Bangkok, Thailand

Tel/Fax +66 89-44I-8456

Email puree.a@chula.ac.th
Risk Management and Healthcare Policy 2020:I3 2753-2768

mit your manuscript

DovePres: in $\square$ 
Drugs are classified into different categories based on their characteristics. Major factors that affect drug classification are the self-diagnosis nature of diseases and safety profile of drugs. Drugs for catastrophic diseases and drugs for minor ailments are usually classified into different categories, which are prescription drugs and non-prescription drugs, respectively. ${ }^{1}$ Drug status can be re-classified downward or upward depending mainly on the safety information being obtained from market experiences. ${ }^{1,2}$ For example, in the UK, diclofenac was re-classified upward from nonprescription to prescription status because an increased risk of cardiovascular diseases was found. ${ }^{3}$ Conversely, to increase drug accessibility, in the US, loratadine was reclassified from prescription to non-prescription status when its safety information was confirmed after placing it on the market for nine years. ${ }^{4}$ There is a precedent, then, that drug regulatory agencies make the final decision when assessing benefits and risks to re-classify drugs into appropriate categories in order to ensure patient safety while maximizing timely access to drugs.

Thailand has been internationally recognized for its successful health development and universal health coverage policy. ${ }^{5}$ Currently, all Thai citizens are covered under one of the three public health insurance schemes: the National Health Security Office (NHSO), the Social Security Office (SSO) and the Civil Services Medical Benefits Scheme (CSMBS). ${ }^{6}$ Thailand has approximately 13,405 public hospitals, 384 private hospitals, 13,510 clinics, 17,069 type 1 modern community pharmacies, and 2865 type 2 drugstores. $^{7,8}$ Type 1 modern community pharmacies can distribute all types of drugs ranging from traditional to western medicines and from household remedies to specially controlled substances (equal to the prescription status). They require a pharmacist on duty during their operating hours; while type 2 drugstores sell limited non-prescription drug items and drug dispensers are certified non-pharmacists. ${ }^{9}$ Since 2005, the Ministry of Public Health has no longer authorized new type 2 drugstore licensing; therefore, the number of type 2 drugstores have been predicted to decline. This was due to concerns regarding illegally dispensing of dangerous drugs, such as antibiotics or antihypertensive drugs, from the certified non-pharmacists. ${ }^{10}$

The Thai Food and Drug Administration (Thai FDA) has classified drugs into four legal categories: specially controlled drugs, dangerous drugs, non-dangerous drugs and household remedies. ${ }^{11}$ Regulatory details of each drug category are shown in Table 1.

As of 2017, Thailand has more than 37,500 drugs registered with the Thai FDA. ${ }^{13}$ Drugs in three categories, specially controlled drugs, dangerous drugs, and household remedies, must be formally designated by the Thai FDA. Drugs that are not included in the three mentioned categories are automatically classified as non-dangerous drugs. This drug classification system has been used in Thailand for more than five decades. ${ }^{12,14}$ Nonetheless; a study conducted in Thailand by Sriwiryanupab and her colleagues has proposed, along with various pharmacist groups in Thailand, that the non-dangerous drug category should be discontinued. ${ }^{15,16}$ In other words, the drug classification system in Thailand should be reformed. This is because non-dangerous drug category was initiated to support existence of type 2 drugstores where certified nonpharmacists can dispense non-dangerous drugs. As type 1 community pharmacies are now sufficient, type 2 drugstores and non-dangerous drug category can be deserted.

Several drugs in Thailand are classified differently when compared to other countries. Many of them are very easy to access, which evidently result in irrational drug use. Examples of the consequences of classic irrational drug use are antibiotic resistance from antibiotics overuse, addiction from tramadol overuse, misuse of hydrochlorothiazide for weight loss, and dextromethorphan and brown mixture (opium preparation) abuse when mixed with beverages or other illicit drugs for recreational

Table I Current Legal Drug Categories and Their Regulatory Details in Thailand ${ }^{11,12}$

\begin{tabular}{|l|l|l|l|l|l|l|l|}
\hline \multirow{2}{*}{ Drug Categories } & \multirow{2}{*}{$\begin{array}{l}\text { Gate } \\
\text { Keeper }\end{array}$} & \multirow{2}{*}{$\begin{array}{l}\text { Prescription } \\
\text { Requirement }\end{array}$} & & \multicolumn{2}{l|}{ Distribution Channel } & \multicolumn{2}{l|}{ Advertising } \\
\cline { 5 - 8 } & & & Hospital & Pharmacy & $\begin{array}{l}\text { Non- } \\
\text { Pharmacy } \\
\text { Retailer }\end{array}$ & $\begin{array}{l}\text { Health } \\
\text { Professional }\end{array}$ & $\begin{array}{l}\text { Direct-to- } \\
\text { Consumer }\end{array}$ \\
\hline Specially controlled drugs & Physician & Yes & Yes & Yes & No & Yes & No \\
Dangerous drugs & Pharmacist & No & Yes & Yes & No & Yes \\
Non-dangerous drugs & None & No & Yes & Yes & No & Yes \\
Household remedies & None & No & Yes & Yes & Yes & Yes & Yes \\
\hline
\end{tabular}


purposes. ${ }^{17-20}$ At the same time, some other drugs in Thailand are more difficult to access than in other countries. In Thailand, cetirizine and ibuprofen are classified as dangerous drugs which need to be kept behind the counter and dispensed by pharmacists. However, these two drugs are classified as general sale list drugs in the US and the UK, and can be sold by non-pharmacy retailers. $4,21,22$

The Thai Drug Act (No. 6) A.D. 2019 was announced in April 2019 as an addendum to the Thai Drug Act A.D. 1967. The main foci of the addendum were to change the renewal process for drug product licensing (from no re-licensing required to renewal every 7 years), to ensure timeline of the marketing authorization process, and to set up an official list of registered external experts or organizations. ${ }^{12,23}$ However, the revision of the drug classification system regarding the number of drug categories, classification criteria, and actual drug classification is an issue not yet resolved. Thus, a comprehensive review of the drug classification system is required to support the revision.

There have been few research studies published comparing drug classification systems worldwide. ${ }^{15,24-26}$ Of these, just one includes Thailand, but this research still does not focus on a comprehensive review of drug classification systems among the countries in the study. ${ }^{15}$ As prescription and non-prescription drug classification systems can be used as regulatory frameworks to ensure the rational use of drugs, this study aims to explore Thailand and other selected countries' regulatory management regarding their respective drug classification systems, the different criteria of drug classification, and how drug regulatory agencies actually classify drugs into different categories. Findings from this study could be used to support the revision of the drug classification system in Thailand.

\section{Methods}

In this study, the focus was on eight countries: the US, the UK, Japan, Canada, Singapore, the Philippines, Malaysia, and Thailand. The first four were chosen as they are rated as having stringent drug regulatory agencies as defined by the World Health Organization (WHO). The remaining three countries are the regional neighbors of Thailand, all being members of Association of South East Asian Nations (ASEAN), and therefore were chosen for their comparability. $^{27-29}$

A targeted review was used as a primary method to gather information regarding the drug classification system specific to each country, the drug classification criteria specific to each drug classification system, and comparative actual drug classification across selected countries. All data searching in this study was conducted up to February 2020.

Data searching was first run through each country's official drug regulatory agency website. Then, complementary data search for further information was conducted through Google scholar with a combination of various search terms: "drug classification", "drug reclassification", "Rx-to-OTC", “drug schedule", "prescription", "nonprescription", "criteria" and each selected country name. The use of manual searching was also employed to ensure complete inclusion of necessary data sources. Grey literature, such as government reports and conference handouts presented by drug regulatory agencies, were also included. Drug regulatory agencies' interviews would be performed when published information was ambiguous or when information was provided in local language.

In order to better understand the drug classification system and criteria of the selected countries, 52 common drugs used for treatment of both chronic and acute diseases were chosen along with various dosage forms to see how categorization affected drug classification. These drugs had been taken from 11 therapeutic groups: dyslipidemia, diabetes, hypertension, bacterial infection, fungal infection, pain, allergy, nausea and vomiting associated with chemotherapy, insomnia, smoking cessation, and vaccines. A targeted review was conducted through government websites and other credible sources, which are shown in Table 2.

Content analysis was performed to identify drug classification category and key criteria used to categorize drugs into different classes. We also investigated healthcare system, rate of education, and socioeconomic status of each country as these factors might affect drug classification system management. Table 3 provides countries' background regarding the healthcare system, country education levels and socioeconomic statuses. The healthcare context itself was separated into three different categories: physician density, pharmacist density, and pharmacists' autonomy to respond to patients' symptoms and vaccinate. Education attainment levels of each country were gaged using the learning-adjusted years of schooling (LAYS), a measurement combining both quantity and quality of schooling. ${ }^{30}$ The socioeconomic status of each country was measured by the human development index (HDI). ${ }^{31,32}$ 
Table 2 Sources of Actual Drug Classification Comparisons Across Different Drug Regulatory Agencies

\begin{tabular}{|c|c|c|}
\hline Country & Source & Reference \\
\hline \multirow[t]{2}{*}{ Canada } & National Drug Schedules & https://napra.ca/national-drug-schedules?keywords=sulindac\&schedule= \\
\hline & Drug Product Database online query & https://health-products.canada.ca/dpd-bdpp/index-eng.jsp \\
\hline \multirow[t]{3}{*}{ Japan } & $\begin{array}{l}\text { Pharmaceuticals and Medical Devices } \\
\text { Agency (PMDA) }\end{array}$ & http://www.pmda.go.jp/english/search_index.html \\
\hline & Ministry of Health Labour and Welfare & https://www.mhlw.go.jp/bunya/iyakuhin/ippanyou/newyoushidou.html \\
\hline & Find OTC medicines & http://search.jsm-db.info/sp_en/ \\
\hline Singapore & Singapore Drugs Database & https://pharmfair.com/ \\
\hline The UK & $\begin{array}{l}\text { The electronic medicines compendium } \\
\text { (emc) }\end{array}$ & $\begin{array}{l}\text { https://www.medicines.org.uk/emc/search?q=drug\&t=advanced\&st=true\&sc= } \\
\text { true\&l=4 }\end{array}$ \\
\hline The US & Drugs@FDA & https://www.accessdata.fda.gov/scripts/cder/daf/ \\
\hline \multirow[t]{2}{*}{ Malaysia } & $\begin{array}{l}\text { Official portal of pharmaceutical services } \\
\text { program }\end{array}$ & $\begin{array}{l}\text { https://www.pharmacy.gov.my/v2/sites/default/files/document-upload/poisons-list } \\
\underline{-25.07 .2019 \_I . p d f}\end{array}$ \\
\hline & Industry and QUEST3+ System & https://quest3plus.bpfk.gov.my/pmo2/index.php \\
\hline \multirow[t]{2}{*}{ The Philippines } & Registered products & https://data.gov.ph/?q=dataset/registered-products \\
\hline & Center for Drug Database 2019 & Personal communication, January $6,2020^{a}$ \\
\hline Thailand & Drug registration database & $\begin{array}{l}\text { http://pertento.fda.moph.go.th/FDA_SEARCH_DRUG/SEARCH_DRUG/FRM_ } \\
\text { SEARCH_DRUG.aspx }\end{array}$ \\
\hline
\end{tabular}

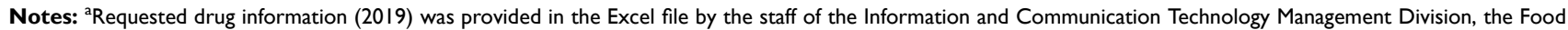
and Drug Administration of the Philippines.

\section{Results}

The results themselves are comprised of three parts: the drug classification system specific to each country, the drug classification criteria specific to each drug classification system, and comparative drug classification across selected countries.

\section{Drug Classification System}

Our research found that, among the eight countries, drugs are universally classified into two major categories: prescription drugs and non-prescription drugs. Prescription drugs are consistently regulated across the eight studied

Table 3 Different System Contexts of the Eight Studied Countries

\begin{tabular}{|c|c|c|c|c|c|c|}
\hline \multirow[t]{2}{*}{ Country } & \multicolumn{4}{|c|}{ Healthcare Context } & \multirow{2}{*}{$\begin{array}{l}\text { Citizen } \\
\text { Education } \\
\text { Levels } \\
(\text { LAYs) }\end{array}$} & \multirow{2}{*}{$\begin{array}{l}\text { Socio- } \\
\text { Economic } \\
\text { Status } \\
(\text { HDI) }\end{array}$} \\
\hline & $\begin{array}{l}\text { Physician } \\
\text { Density } \\
\text { (Per 10,000 }^{\text {Populations) }}{ }^{34}\end{array}$ & $\begin{array}{l}\text { Pharmacist } \\
\text { Density } \\
\text { (Per 10,000 }^{\text {Populations) }}{ }^{35}\end{array}$ & $\begin{array}{l}\text { Pharmacists Can } \\
\text { Respond to Patients' } \\
\text { Symptoms }\end{array}$ & $\begin{array}{l}\text { Pharmacists } \\
\text { Can Vaccinate. }\end{array}$ & & \\
\hline Canada & 26.10 & 11.24 & $\mathrm{Yes}^{36}$ & Yes $^{b, 37}$ & 11.7 & Very High \\
\hline Japan & 24.12 & 18.02 & $\mathrm{No}^{38}$ & No ${ }^{37}$ & 12.3 & Very High \\
\hline Singapore & 23.06 & 5.09 & Yes $^{39}$ & No ${ }^{40}$ & 12.9 & Very High \\
\hline The UK & 28.06 & 8.89 & $Y_{e s}^{41}$ & $\mathrm{Yes}^{37}$ & 11.5 & Very High \\
\hline The US & 25.95 & 9.25 & $\mathrm{No}^{42}$ & $Y_{e s}{ }^{37}$ & II.I & Very High \\
\hline Malaysia & 15.13 & 3.47 & $Y_{e s}^{43}$ & $\mathrm{No}^{44}$ & 9.1 & High \\
\hline The Philippines & 12.75 & 3.31 & $Y_{e s}^{45}$ & $\mathrm{Yes}^{46}$ & 8.4 & Medium \\
\hline Thailand & 8.10 & 5.53 & $Y_{e s}{ }^{47}$ & No ${ }^{47}$ & 8.6 & High \\
\hline
\end{tabular}

Notes: ${ }^{a}$ Only certified pharmacists can vaccinate. ${ }^{\mathrm{b}}$ The regulations vary among the provinces/territories of Canada. Some of them are not allowed to vaccinate. Abbreviations: LAYs, learning-adjusted years of schooling; HDI, human development index. 
countries. To access prescription drugs, physicians must diagnose a disease before providing prescriptions to patients. However, some regulations vary across countries. Within our sample, though excluding the US and Canada, prescription drugs cannot be directly advertised to consumers. $^{48-56}$ Moreover, prescription drugs are mainly distributed through community pharmacies and hospitals. Online pharmacies are permitted to sell prescription drugs in the US, the UK, Singapore, the Philippines, and Canada, but not yet in Japan, Malaysia and Thailand. ${ }^{12,43,45,57-67}$

On the other hand, non-prescription drugs are diversely regulated across countries. The numbers of these subcategories ranged from one in the US to four in Japan (Figure 1). Although the regulations of the nonprescription drug category varied, they could be grouped into the following four sub-categories (Table 4).

\section{Behind-the-Counter (BTC) Drug Category}

BTC drugs do not require prescriptions but do require dispensing under pharmacists' supervision, and, as a result, these drugs are kept behind the pharmacy counters. Pharmacists must ask for patients' symptoms before dispensing any drugs. Detailed instructions are also required to ensure that patients understand how to use the drug safely. Six countries have implemented BTC as an official drug category, though the official name of the category differs in each: pharmacy drugs (the UK and Singapore), group C (Malaysia), over-the-counter drugs (the Philippines), schedule 2 (Canada), and dangerous drugs (Thailand). ${ }^{12,43,45,58,60,61,63-67}$ These drugs are permitted to be sold via online pharmacies in most countries, except Malaysia and Thailand. Direct-to-consumer advertisements of BTC drugs are permitted only in the UK, Singapore and Canada; but not allowed in Malaysia, the Philippines and Thailand. ${ }^{48-56}$

\section{Open-Shelf (OPS) Drug Category}

OPS drugs have been deemed safe for consumers to practice self-medication; although drugs are still confined to distribution only in healthcare settings, and not in nonpharmacy retailers. This implies that patients could seek pharmacist advice if needed. Only Canada and Thailand have implemented the OPS drug category, which is called schedule 3 and non-dangerous drugs, respectively. In Thailand, OPS drugs can be sold in type 2 drugstores that are operated by certified non-pharmacists. OPS drugs are permitted to be sold via online pharmacies in Canada,

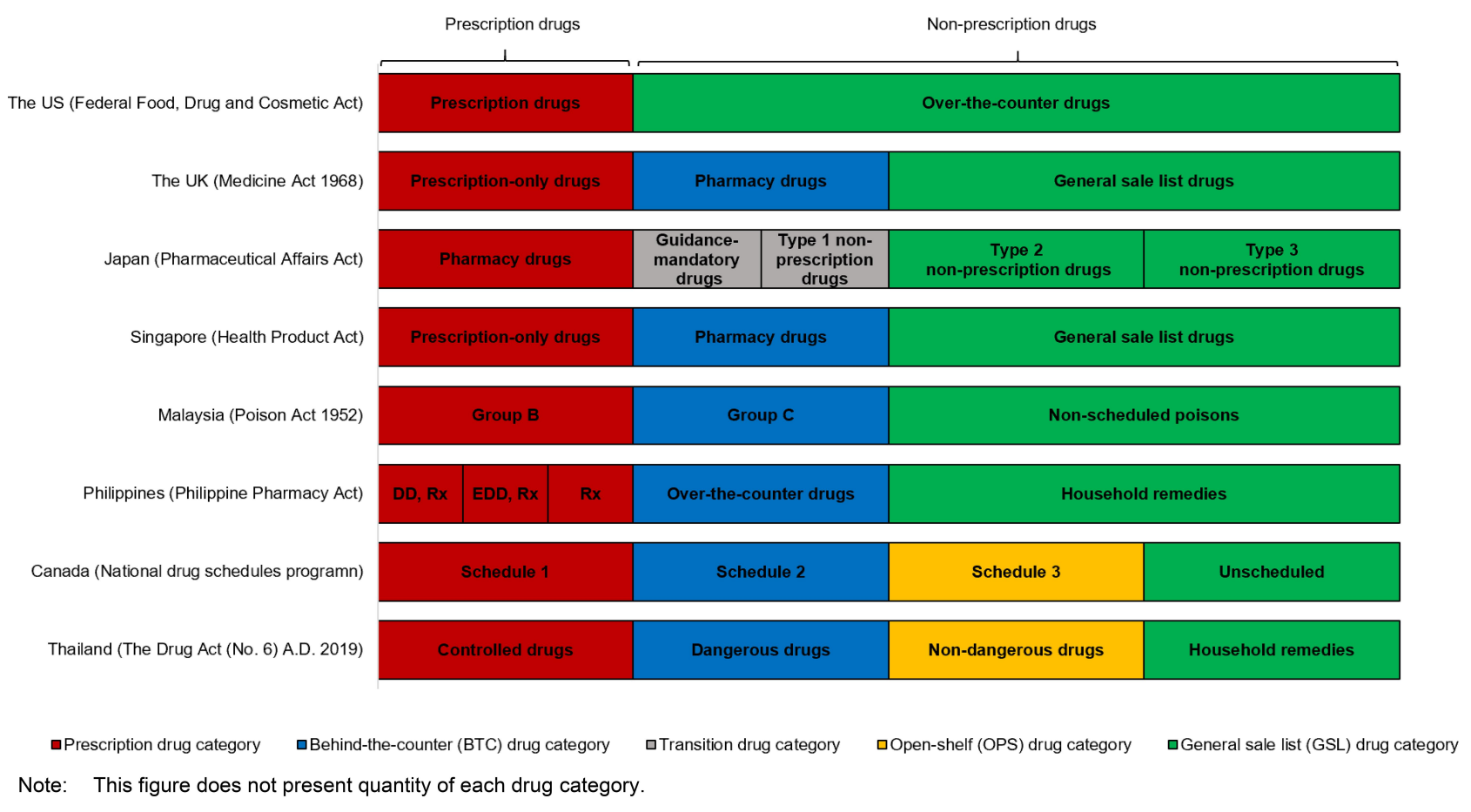

Abbreviation: DD, dangerous drugs; EDD, exempted dangerous drugs; Rx, prescription drugs

Figure I Drug classification categories among countries.

Note: Data from references 12, 43, 45, and 57-61. 
Table 4 Differences in Drug Regulation Among Each Drug Category $12,43,45,48-67$

\begin{tabular}{|c|c|c|c|c|c|}
\hline \multirow[t]{2}{*}{ Regulations } & \multicolumn{5}{|l|}{ Drug Categories } \\
\hline & Prescription & BTC & OPS & GSL & Transition \\
\hline $\begin{array}{l}\text { Countries in which the categories are } \\
\text { implemented }\end{array}$ & All selected countries & $\begin{array}{l}\text { UK, SG, MY, PH, CA, } \\
\text { TH }\end{array}$ & $\mathrm{CA}, \mathrm{TH}$ & All selected countries & $J P$ \\
\hline Gate keeper & Physician & Pharmacist & None & None & Pharmacist \\
\hline Prescription requirement for purchasing & Yes & No & No & No & No \\
\hline \multicolumn{6}{|l|}{ Distribution channels } \\
\hline Hospitals & Yes & Yes & Yes & Yes & Yes \\
\hline Retail pharmacies & Yes & Yes & Yes & Yes & Yes \\
\hline Online pharmacies & $\begin{array}{l}\text { Yes: US, UK, SG, PH, } \\
\text { CA } \\
\text { No: JP, MY, TH }\end{array}$ & $\begin{array}{l}\text { Yes: UK, SG, PH, CA } \\
\text { No: MY, TH }\end{array}$ & $\begin{array}{l}\text { Yes: CA } \\
\text { No: TH }\end{array}$ & $\begin{array}{l}\text { Yes: all selected } \\
\text { countries }\end{array}$ & Yes: JP ${ }^{a}$ \\
\hline Non-pharmacy retailers & No & No & No & Yes & No \\
\hline $\begin{array}{l}\text { Permission of direct-to-consumer } \\
\text { advertisement }\end{array}$ & US, $C^{b}$ & UK, SG, CA & CA, TH & All selected countries & $J P$ \\
\hline
\end{tabular}

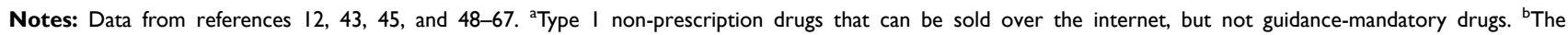
advertisement in Canada cannot mention the benefits or risks of drugs.

Abbreviations: BTC, behind-the-counter drugs; OPS, open-shelf drugs; GSL, general sale list drugs; US, the United States; UK, the United Kingdom; JP, Japan; SG, Singapore; MY, Malaysia; PH, the Philippines; CA, Canada; TH, Thailand.

but not in Thailand. Direct-to-consumer advertisements are permitted in both countries. ${ }^{12,50,51,61,65}$

\section{General Sale List (GSL) Drug Category}

GSL drugs have been declared safe for self-medication. All studied countries have this drug category and they can be sold in non-pharmacy retailers and over the internet. $^{12,43,45,57-67}$ Direct-to-consumer advertisements of GSL drugs are also permitted in all sample countries. ${ }^{48-56}$ The GSL drug category has a different nomenclature across the eight countries: over-the-counter drugs (the US), general sale list drugs (the UK and Singapore), type 2 non-prescription drugs and type 3 non-prescription drugs (Japan), non-scheduled poisons (Malaysia), household remedies (the Philippines and Thailand) and unscheduled drugs (Canada).

\section{Transitional Drug Category}

We also found a transitional drug category in Japan. When drugs are re-classified from prescription to GSL drugs, they are then relegated to the guidance-mandatory drug category in order to examine the safety of the drug and to monitor consumer self-medication behavior. Drugs in the guidance-mandatory category required face-to-face pharmacist dispensing. It takes at least three years to monitor drugs under the guidance-mandatory label. Once evidence of drug safety is established and confirmed, guidance- mandatory drugs are then re-classified as type 1 nonprescription drugs and remain in this status for at least one year for safety monitoring purposes. Since the distribution of type 1 non-prescription drugs is more relaxed than guidance-mandatory drugs, they can be sold via internet, although pharmacists' supervision is still required. Pharmacists must assess the necessity of drug use and instruct patients to appropriately use any dispensed drugs. Methods of contact other than face-to-face interaction, such as by email or telephone, can be used to ensure proper drug use. Having established the safety of a type 1 non-prescription drug, these can then be reclassified into type 2 and type 3 non-prescription drugs for selfmedication without pharmacist supervision. ${ }^{24,59}$

\section{Dissimilarities Between the Sample Countries' Categorization}

The similarities within the drug categories of the eight sample countries have been summarized above. Some unique dissention points are reviewed below.

The US is the only country with a two-drug classification system: prescription drugs and over-the-counter drugs (GSL drug category) ${ }^{68}$ There is no BTC drug category in the US, although some OTC drugs under the GSL drug category, such as pseudoephedrine, need to be strictly kept behind the pharmacist's counter and dispensed only by 
pharmacists. $^{69}$ This management process mimics the BTC drug category. ${ }^{2}$

In Japan, it is not only the transitional drug category which is implemented to ensure safety when downward reclassification occurs. A strict self-medication handling mechanism is present wherein type 2 and 3 non-prescription drugs can be sold by non-pharmacy retailers, yet still require specially certified personnel to dispense them. ${ }^{24,59}$

In Canada, Health Canada and the National Association of Pharmacy Regulatory Authorities are responsible for drug classification in Canadian provinces and territories, and implement four drug categories nationwide. However, how drugs are placed into these centralized categories are not always uniform. The provinces of British Columbia, Newfoundland and Labrador, and Quebec all have their own drug regulatory agencies, wherein a drug which is classified under the BTC drug category in the province of British Columbia may be categorized as OPS drugs in Quebec. Inconsistency of drug classification has therefore been noted between provinces and territories in Canada. ${ }^{70}$

In Malaysia, drugs are regulated under the "Poison Act" along with other poisonous substances, while in other countries, drugs are regulated under the drug act. The Poison Act has classified substances into four categories; group A, group B, group C, and group D. Group A poisons are highly toxic substances that are not allowed to be sold under any circumstances, while group D poisons are chemical substances used in a laboratory. Only group B (prescription drug category) and group C (BTC drug category) are considered drugs for medical consumption. Non-scheduled drugs exempted from the Poison Act 1952 are considered as "non-scheduled poisons" or GSL drugs. ${ }^{43}$

In the Philippines, drugs which require prescriptions can be divided into three categories. The first category, called "dangerous drugs", is made up of narcotic and psychotropic drugs listed in the Comprehensive Dangerous Drugs Act of 2000 and requires a special prescription form (yellow Rx) to supply. The second category, called "exempted dangerous drugs", contains controlled substances that are exempt from dangerous drug category if they meet certain criteria. The third category is prescription-only medicines, which are general drugs that require prescriptions to be dispensed. ${ }^{45,71}$

This study found that drug re-classification across all sample countries can be divided into two types: reclassification by active pharmaceutical ingredient (API), which was found in Canada, Thailand, Malaysia, and the
Philippines, and re-classification by specific product brand, which was found in the US, the UK, Japan, and Singapore. There are pros and cons to either system. The reclassification by API across all product brands is easier for management. Brand-specific re-classification, in contrast, tends to accommodate market exclusivity. ${ }^{72}$ Under the market exclusivity period, a solicited company needs to undertake post-marketing surveillance to support reclassification and is also granted an exclusive period to make back their investment during the re-classification process. The exclusivity period can range from 1 year in the UK and Singapore to 3 years in the US and Japan. ${ }^{72-77}$

\section{Drug Classification Criteria}

The drug classification criteria from the eight sample countries were obtained mostly from drug regulatory agency websites. Half of the studied countries (the US, Japan, Malaysia, and the Philippines) published only the principles of their respective drug classification criteria in small detail, while the other half (the UK, Singapore, Canada, and Thailand) published detailed drug classification criteria. Table 5 summarizes the degree of information which can be found for each country's drug classification criteria. The table indicates "Yes" only when the criteria were explicitly mentioned, while blank cells mark a lack of explicitly published classification criteria.

This study found that the drug classification criteria are comprised of three themes: i) disease characteristics, ii) drug safety profiles, and iii) other drug characteristics.

The common criteria of drug classification explicitly mentioned across the eight countries were i) "Requires disease diagnosis from healthcare professional", ii) "The drug requires evaluation or management by a healthcare professional", and iii) "The drug resulted in potentially negative consequences, especially habit-forming drugs". Among these three criteria, "Requires a disease diagnosis from a healthcare professional" is usually the first discriminating criteria to filter prescription from non-prescription drugs. If a layperson cannot accurately identify their illness, drugs indicated for that illness cannot be classified as nonprescription drugs. However, if a layperson can identify their illness, but indicated drugs require evaluation or management by a healthcare professional, then those drugs must be classified as prescription drugs. If a layperson can identify their illness and the corresponding drugs do not require a health professional's evaluation or management, but those drugs could have potentially negative consequences, then those drugs must be considered as prescription drugs. 
Table 5 Drug Classification Criteria Among the Eight Countries ${ }^{11,22,58,78-87}$

\begin{tabular}{|c|c|c|c|c|c|c|c|c|}
\hline Drug Classification Criteria & US & UK & $\mathbf{J P}$ & SG & MY & $\mathbf{P H}$ & CA & TH \\
\hline \multicolumn{9}{|l|}{ Disease characteristics } \\
\hline $\begin{array}{l}\text { 1. Requires a disease diagnosis from a healthcare professional } \\
\text { 2. Requires subsequent disease monitoring } \\
\text { 3. Demands timely access to drugs } \\
\text { 4. Nature of the disease: acute, chronic, or recurring }\end{array}$ & $\begin{array}{l}\text { Yes } \\
\text { Yes }\end{array}$ & $\begin{array}{l}\text { Yes } \\
\text { Yes } \\
\text { Yes } \\
\text { Yes }^{\mathrm{a}}\end{array}$ & $\begin{array}{l}\text { Yes } \\
\text { Yes } \\
\text { Yes }\end{array}$ & $\begin{array}{l}\text { Yes } \\
\text { Yes }\end{array}$ & Yes & $\begin{array}{l}\text { Yes } \\
\text { Yes }\end{array}$ & $\begin{array}{l}\text { Yes } \\
\text { Yes } \\
\text { Yes } \\
\text { Yes }^{b}\end{array}$ & Yes \\
\hline \multicolumn{9}{|l|}{ Drug safety profile } \\
\hline $\begin{array}{l}\text { I. The drug requires evaluation or management by a healthcare professional } \\
\text { I.I Severe side effects } \\
\text { I.2 A narrow safety margin (such as a narrow therapeutic index) } \\
\text { I.3 Drug interaction } \\
\text { I.4 High risk in vulnerable populations c } \\
\text { 2. The drug resulted in potentially negative consequences } \\
\text { 2.I Habit forming } \\
\text { 2.2 Misuse } \\
\text { 2.3 Masking serious diseases' symptoms } \\
2.4 \text { Micro-organism resistant } \\
2.5 \text { Have a negative impact on reproductive system } \\
\text { or genetic, or was a mutagenic agent } \\
\text { 3. Other safety issues/More information needed } \\
\text { 3.I Comparative risk with other drugs with the same } \\
\text { indication } \\
\text { 3.2 Assured effectiveness }\end{array}$ & $\begin{array}{l}\text { Yes } \\
\text { Yes }\end{array}$ & $\begin{array}{l}\text { Yes } \\
\text { Yes } \\
\text { Yes } \\
\text { Yes } \\
\text { Yes } \\
\text { Yes } \\
\text { Yes } \\
\text { Yes }\end{array}$ & $\begin{array}{l}\text { Yes } \\
\text { Yes } \\
\text { Yes } \\
\text { Yes } \\
\text { Yes } \\
\text { Yes } \\
\text { Yes } \\
\text { Yes }\end{array}$ & $\begin{array}{l}\text { Yes } \\
\text { Yes } \\
\text { Yes }\end{array}$ & Yes & $\begin{array}{l}\text { Yes } \\
\text { Yes } \\
\text { Yes } \\
\text { Yes } \\
\text { Yes } \\
\text { Yes } \\
\text { Yes }\end{array}$ & $\begin{array}{l}\text { Yes } \\
\text { Yes } \\
\text { Yes } \\
\text { Yes } \\
\text { Yes } \\
\text { Yes } \\
\text { Yes } \\
\text { Yes } \\
\text { Yes }\end{array}$ & $\begin{array}{l}\text { Yes } \\
\text { Yes } \\
\text { Yes } \\
\text { Yes } \\
\text { Yes } \\
\text { Yes } \\
\text { Yes }\end{array}$ \\
\hline \multicolumn{9}{|l|}{ Other drug characteristics } \\
\hline $\begin{array}{l}\text { 1. Must be administered at health care facilities } \\
\text { 2. Injection dosage form } \\
\text { 3. Need special storage and handling } \\
\text { 4. Pack size }\end{array}$ & & $\begin{array}{l}\text { Yes } \\
\text { Yes }^{\text {d }} \\
\text { Yes }^{\text {h }}\end{array}$ & & $\begin{array}{l}\text { Yes } \\
\text { Yes }^{d} \\
\text { Yes }^{\mathrm{g}}\end{array}$ & & & $\begin{array}{l}\text { Yes } \\
\text { Yes }^{\mathrm{e}}\end{array}$ & $\begin{array}{l}\text { Yes }^{f} \\
\text { Yes }^{i}\end{array}$ \\
\hline
\end{tabular}

Notes: Data from references II, 22, 58, and 78-87. a'Drugs for recurring symptoms or chronic diseases were classified as prescription or BTC drugs in the UK. 'Drugs for recurring symptoms or chronic diseases were classified as prescription, BTC or OPS drugs in Canada. 'Vulnerable people refer to children, pregnant woman, breastfeeding and patients suffering from liver and renal dysfunction. Injection drugs were classified as prescription drugs in the UK and Singapore. ${ }^{\mathrm{e}}$ Injection drugs were classified as prescription or BTC drugs in Canada. Injection drugs cannot be classified as non-dangerous drugs and household remedies in Thailand. ${ }^{8}$ Drugs requiring special storage or management were classified as prescription or BTC drugs in Singapore. ${ }^{\mathrm{G}} \mathrm{GL}$ drugs in the UK should be dispensed in small pack size to prevent possible harm from longterm use or delayed diagnosis of conditions that require different drugs. The larger pack size is classified into BTC drug category. 'In Thailand, GSL drugs must be in suitable pack size for self-treatment. Larger pack size is classified as OPS drugs.

Abbreviations: US, the United States; UK, the United Kingdom; JP, Japan; SG, Singapore; MY, Malaysia; PH, the Philippines; CA, Canada; TH, Thailand.

Other common criteria explicitly mentioned in at least half of the studied countries were "requires subsequent disease monitoring" (the US, the UK, Singapore, the Philippines, and Canada), "misuse" (the US, the UK, Japan, Canada, and Thailand), and "injection dosage form" (the UK, Singapore, Canada, and Thailand). The UK and Singapore classified injections as prescription status, while Canada and Thailand classified injections as either prescription or BTC drugs.

Other less commonly explicit criteria worth mentioning are "micro-organism resistant" (Canada), "masking serious diseases' symptoms" (the UK, Singapore, Canada), "need special storage and handling" (Singapore), and "pack size" (the UK, Thailand). It should be noted that, though microorganism resistance is a known global issue, as of this writing only one country lists it as an explicit criteria for drug classification. ${ }^{11,22,58,78-87}$

\section{Actual Drug Classification}

Fifty-two common drugs for 11 indications were selected to compare their actual drug classification across different drug regulatory agencies. The actual drug classification is presented in Table 6. They were obtained from official drug regulatory sources between August 2019 and February 2020. 
Table 6 Actual Drug Classification of Selected Drugs Across Different Drug Regulatory Agencies (Updated in February 2020)

\begin{tabular}{|c|c|c|c|c|c|c|c|c|c|c|}
\hline Indication & Drug & $\begin{array}{l}\text { Strength and } \\
\text { Dosage } \\
\text { Form }\end{array}$ & US & UK & JP & SG & MY & $\mathbf{P H}$ & CA & TH \\
\hline Insomnia & $\begin{array}{l}\text { Alprazolam } \\
\text { Alprazolam } \\
\text { Lorazepam } \\
\text { Diazepam }\end{array}$ & $\begin{array}{l}0.4 \mathrm{mg} \text { tab } \\
0.5 \mathrm{mg} \mathrm{tab} \\
1 \mathrm{mg} \text { tab } \\
5 \mathrm{mg} \mathrm{tab}\end{array}$ & $\begin{array}{l}- \\
P \\
P \\
P\end{array}$ & $\begin{array}{l}- \\
P \\
P \\
P\end{array}$ & $\begin{array}{l}\mathrm{P} \\
- \\
\mathrm{P} \\
\mathrm{P}\end{array}$ & $\begin{array}{l}- \\
P \\
P \\
P\end{array}$ & $\begin{array}{l}- \\
P \\
P \\
P\end{array}$ & $\begin{array}{l}- \\
\mathrm{P}^{\mathrm{a}} \\
\mathrm{P}^{\mathrm{a}} \\
\mathrm{P}^{\mathrm{a}}\end{array}$ & $\begin{array}{l}- \\
P \\
P \\
P\end{array}$ & $\begin{array}{l}- \\
P^{b} \\
P^{b} \\
P^{b}\end{array}$ \\
\hline $\begin{array}{l}\text { Nausea and vomiting } \\
\text { associated with } \\
\text { chemotherapy }\end{array}$ & $\begin{array}{l}\text { Ondansetron } \\
\text { Ondansetron } \\
\text { Granisetron }\end{array}$ & $\begin{array}{l}4 \mathrm{mg} \text { tab } \\
8 \mathrm{mg} \text { tab } \\
1 \mathrm{mg} \text { tab }\end{array}$ & $\begin{array}{l}P \\
P \\
P\end{array}$ & $\begin{array}{l}\mathrm{P} \\
\mathrm{P} \\
\mathrm{P}\end{array}$ & $\begin{array}{l}\mathrm{P} \\
- \\
\mathrm{P}\end{array}$ & $\begin{array}{l}P \\
P \\
P\end{array}$ & $\begin{array}{l}\mathrm{P} \\
\mathrm{P} \\
\mathrm{P}\end{array}$ & $\begin{array}{l}P \\
P \\
-\end{array}$ & $\begin{array}{l}P \\
P \\
P\end{array}$ & $\begin{array}{l}P \\
P \\
P\end{array}$ \\
\hline Dyslipidemia & $\begin{array}{l}\text { Simvastatin } \\
\text { Atorvastatin } \\
\text { Gemfibrozil } \\
\text { Fenofibrate }\end{array}$ & $\begin{array}{l}10 \mathrm{mg} \text { tab } \\
20 \mathrm{mg} \text { tab } \\
600 \mathrm{mg} \text { tab } \\
200 \mathrm{mg} \text { tab }\end{array}$ & $\begin{array}{l}P \\
P \\
P \\
P\end{array}$ & $\begin{array}{l}P \\
P \\
P \\
P\end{array}$ & $\begin{array}{l}P \\
P \\
- \\
-\end{array}$ & $\begin{array}{l}P \\
P \\
P \\
P\end{array}$ & $\begin{array}{l}P \\
P \\
P \\
P\end{array}$ & $\begin{array}{l}P \\
P \\
P \\
P\end{array}$ & $\begin{array}{l}P \\
P \\
P \\
P\end{array}$ & $\begin{array}{l}\text { BTC } \\
\text { BTC } \\
\text { BTC } \\
\text { BTC }\end{array}$ \\
\hline Hypertension & $\begin{array}{l}\text { HCTZ } \\
\text { Propranolol } \\
\text { Enalapril } \\
\text { Enalapril } \\
\text { Losartan }\end{array}$ & $\begin{array}{l}50 \mathrm{mg} \text { tab } \\
10 \mathrm{mg} \mathrm{tab} \\
5 \mathrm{mg} \text { tab } \\
10 \mathrm{mg} \mathrm{tab} \\
50 \mathrm{mg} \mathrm{tab}\end{array}$ & $\begin{array}{l}P \\
P \\
P \\
P \\
P\end{array}$ & $\begin{array}{l}- \\
P \\
P \\
P \\
P\end{array}$ & $\begin{array}{l}P \\
P \\
P \\
P \\
P\end{array}$ & $\begin{array}{l}P \\
P \\
P \\
P \\
P\end{array}$ & $\begin{array}{l}P \\
P \\
P \\
P \\
P\end{array}$ & $\begin{array}{l}P \\
P \\
P \\
P \\
P\end{array}$ & $\begin{array}{l}P \\
P \\
P \\
P \\
P\end{array}$ & $\begin{array}{l}\text { BTCl } \\
\text { OPS }^{\text {e }} \\
\text { BTC } \\
\text { BTC } \\
\text { BTC } \\
\text { BTC }\end{array}$ \\
\hline Diabetes & $\begin{array}{l}\text { Metformin } \\
\text { Glipizide } \\
\text { Glimepiride } \\
\text { Sitagliptin } \\
\text { Linagliptin }\end{array}$ & $\begin{array}{l}500 \mathrm{mg} \text { tab } \\
5 \mathrm{mg} \text { tab } \\
1 \mathrm{mg} \text { tab } \\
100 \mathrm{mg} \text { tab } \\
5 \mathrm{mg} \mathrm{tab}\end{array}$ & $\begin{array}{l}P \\
P \\
P \\
P \\
P\end{array}$ & $\begin{array}{l}\mathrm{P} \\
\mathrm{P} \\
\mathrm{P} \\
\mathrm{P} \\
\mathrm{P}\end{array}$ & $\begin{array}{l}P \\
- \\
P \\
P \\
P\end{array}$ & $\begin{array}{l}P \\
P \\
P \\
P \\
P\end{array}$ & $\begin{array}{l}\text { BTC } \\
\text { BTC } \\
\text { BTC } \\
\text { P } \\
\text { P }\end{array}$ & $\begin{array}{l}P \\
P \\
P \\
P \\
P\end{array}$ & $\begin{array}{l}P \\
P \\
P \\
P \\
P\end{array}$ & $\begin{array}{l}\text { BTC } \\
\text { BTC } \\
\text { BTC } \\
\text { BTC } \\
\text { BTC }\end{array}$ \\
\hline Bacterial infection & $\begin{array}{l}\text { Amoxicillin } \\
\text { Levofloxacin } \\
\text { Azithromycin } \\
\text { Azithromycin } \\
\text { Doxycycline } \\
\text { Clindamycin }\end{array}$ & $\begin{array}{l}250 \mathrm{mg} \text { cap } \\
250 \mathrm{mg} \text { tab } \\
250 \mathrm{mg} \text { cap } \\
200 \mathrm{mg} / 5 \mathrm{ml} \\
100 \mathrm{mg} \text { cap } \\
150 \mathrm{mg} \text { cap }\end{array}$ & $\begin{array}{l}P \\
P \\
P \\
P \\
P \\
P\end{array}$ & $\begin{array}{l}P \\
P \\
P \\
P \\
P \\
P\end{array}$ & $\begin{array}{l}P \\
P \\
P \\
- \\
P \\
P\end{array}$ & $\begin{array}{l}P \\
P \\
P \\
P \\
P \\
P\end{array}$ & $\begin{array}{l}P \\
P \\
P \\
P \\
P \\
P\end{array}$ & $\begin{array}{l}P \\
P \\
P \\
P \\
P \\
P\end{array}$ & $\begin{array}{l}P \\
P \\
P \\
P \\
P \\
P\end{array}$ & $\begin{array}{l}\text { BTC } \\
\text { BTC } \\
\text { BTC } \\
\text { BTC } \\
\text { BTC } \\
\text { BTC }\end{array}$ \\
\hline Fungal infection & $\begin{array}{l}\text { Clotrimazole } \\
\text { Ketoconazole } \\
\text { Ketoconazole }\end{array}$ & $\begin{array}{l}1 \% \text { cream } \\
2 \% \text { cream } \\
200 \mathrm{mg} \mathrm{tab}\end{array}$ & $\begin{array}{l}P / G S L^{d} \\
P \\
P\end{array}$ & $\begin{array}{l}\text { BTC/GSL }^{d} \\
P / B T C / G S L^{d} \\
P\end{array}$ & $\begin{array}{l}P / T^{d} \\
P \\
-\end{array}$ & $\begin{array}{l}\text { GSL } \\
\text { BTC/GSL }^{d} \\
\text { P }\end{array}$ & $\begin{array}{l}\text { GSL } \\
\text { BTC } \\
P\end{array}$ & $\begin{array}{l}\mathrm{P} \\
\mathrm{GSL} \\
-\end{array}$ & $\begin{array}{l}\text { GSL } \\
P \\
P\end{array}$ & $\begin{array}{l}\text { OPS } \\
\text { BTC } \\
\text { BTC }\end{array}$ \\
\hline Pain & $\begin{array}{l}\text { Ibuprofen } \\
\text { Ibuprofen } \\
\text { Celecoxib } \\
\text { Diclofenac } \\
\mathrm{Na} \\
\text { Diclofenac K } \\
\text { Piroxicam }\end{array}$ & $\begin{array}{l}200 \mathrm{mg} \text { cap } \\
400 \mathrm{mg} \text { tab } \\
200 \mathrm{mg} \text { cap } \\
25 \mathrm{mg} \text { tab } \\
25 \mathrm{mg} \mathrm{tab} \\
20 \mathrm{mg} \mathrm{tab}\end{array}$ & $\begin{array}{l}\text { GSL } \\
P \\
P \\
P \\
P \\
P\end{array}$ & $\begin{array}{l}\text { BTC/GSL }^{d} \\
\text { P/BTC/GSL }^{d} \\
\text { P/BTC }^{c} \\
P \\
P \\
P\end{array}$ & $\begin{array}{l}\mathrm{P} / \mathrm{GSL}^{\mathrm{d}} \\
- \\
\mathrm{P} \\
\mathrm{P} \\
- \\
\mathrm{P}\end{array}$ & $\begin{array}{l}\text { P/BTC/GSL }{ }^{c, d} \\
P / B T C \\
P \\
P \\
P \\
P\end{array}$ & $\begin{array}{l}\text { BTC } \\
\text { BTC } \\
\text { P } \\
\text { BTC } \\
- \\
\text { BTC }\end{array}$ & $\begin{array}{l}\text { BTC } \\
\text { BTC } \\
\text { P } \\
\text { P } \\
\text { BTC } \\
\text { P }\end{array}$ & $\begin{array}{l}\text { GSL } \\
G S L \\
P \\
P \\
P \\
P\end{array}$ & $\begin{array}{l}\text { BTC } \\
\text { BTC } \\
\text { BTC } \\
\text { BTC } \\
\text { BTC } \\
\text { BTC }\end{array}$ \\
\hline Allergy & $\begin{array}{l}\text { Hydroxyzine } \\
\text { Cetirizine } \\
\text { Cetirizine } \\
\text { Loratadine } \\
\text { Levocetirizine } \\
\text { Desloratadine }\end{array}$ & $\begin{array}{l}10 \mathrm{mg} \text { tab } \\
10 \mathrm{mg} \text { tab } \\
1 \mathrm{mg} / \mathrm{mL} \text { syrup } \\
10 \mathrm{mg} \mathrm{tab} \\
5 \mathrm{mg} \mathrm{tab} \\
5 \mathrm{mg} \mathrm{tab}\end{array}$ & $\begin{array}{l}\mathrm{P} \\
\text { GSL } \\
\text { P/GSL } \\
\text { GSL } \\
P \\
P\end{array}$ & $\begin{array}{l}\text { P } \\
\text { P/BTC/GSL } \\
\text { BTC/GSL }^{d} \\
\text { P/BTC/GSL } \\
\text { P } \\
\text { P }\end{array}$ & $\begin{array}{l}P \\
P / G S L^{d} \\
- \\
P / T^{d, g} \\
P \\
P\end{array}$ & $\begin{array}{l}\mathrm{P} \\
{\mathrm{P} / G S L^{d}}^{\mathrm{d}} \\
\text { BTC/GSL }^{\mathrm{d}} \\
\text { BTC/GSL }^{\mathrm{d}} \\
{\mathrm{P} / \mathrm{BTC}^{\mathrm{c}}} \\
{\mathrm{P} / \mathrm{BTC}^{\mathrm{c}}}\end{array}$ & $\begin{array}{l}\text { BTC } \\
\text { BTC } \\
\text { BTC } \\
\text { BTC } \\
\text { BTC } \\
\text { BTC }\end{array}$ & $\begin{array}{l}\text { P } \\
\text { BTC } \\
\text { BTC } \\
\text { BTC } \\
\text { P } \\
\text { P }\end{array}$ & $\begin{array}{l}\text { P } \\
\text { GSL } \\
\text { OPS } \\
\text { GSL } \\
- \\
\text { GSL }\end{array}$ & $\begin{array}{l}\text { BTC } \\
\text { BTC } \\
\text { BTC } \\
\text { BTC/OPS }^{\text {h }} \\
\text { BTC } \\
\text { BTC }\end{array}$ \\
\hline
\end{tabular}


Table 6 (Continued).

\begin{tabular}{|c|c|c|c|c|c|c|c|c|c|c|}
\hline Indication & Drug & $\begin{array}{l}\text { Strength and } \\
\text { Dosage } \\
\text { Form }\end{array}$ & US & UK & $\mathbf{J P}$ & SG & MY & PH & CA & TH \\
\hline Smoking cessation & $\begin{array}{l}\text { Nicotine } \\
\text { Nicotine } \\
\text { Nicotine } \\
\text { Nicotine } \\
\text { Nicotine }\end{array}$ & $\begin{array}{l}2 \mathrm{mg} \text { gums } \\
4 \mathrm{mg} \text { gums } \\
2 \mathrm{mg} \text { loz } \\
4 \mathrm{mg} \text { loz } \\
\text { Patches }\end{array}$ & $\begin{array}{l}\text { GSL } \\
\text { GSL } \\
\text { GSL } \\
\text { GSL } \\
\text { GSL }\end{array}$ & $\begin{array}{l}\text { GSL } \\
\text { GSL } \\
\text { GSL } \\
\text { GSL } \\
\text { GSL }\end{array}$ & $\begin{array}{l}\text { GSL } \\
- \\
- \\
- \\
{\mathrm{P} / \mathrm{T}^{\mathrm{d}}}\end{array}$ & $\begin{array}{l}\text { BTC } \\
\text { BTC } \\
\text { BTC } \\
- \\
\text { BTC }\end{array}$ & $\begin{array}{l}\text { BTC } \\
\text { BTC } \\
\text { BTC } \\
\text { BTC } \\
\text { BTC }\end{array}$ & $\begin{array}{l}\text { BTC } \\
- \\
\text { BTC } \\
\text { BTC } \\
-\end{array}$ & $\begin{array}{l}\text { GSL } \\
\text { GSL } \\
- \\
- \\
\text { GSL }\end{array}$ & $\begin{array}{l}\text { OPS } \\
\text { OPS } \\
\text { BTC } \\
\text { BTC } \\
\text { OPS }\end{array}$ \\
\hline Vaccines & $\begin{array}{l}\text { BCG } \\
\text { IPV } \\
\text { Influenza } \\
\text { MMR } \\
\text { Rabies }\end{array}$ & $\begin{array}{l}\text { Injections } \\
\text { Injections } \\
\text { Injections } \\
\text { Injections } \\
\text { Injections }\end{array}$ & $\begin{array}{l}P^{i} \\
P^{i} \\
P^{i} \\
P^{i} \\
P^{i}\end{array}$ & $\begin{array}{l}P \\
P \\
P \\
P \\
P\end{array}$ & $\begin{array}{l}P \\
P \\
P \\
- \\
P\end{array}$ & $\begin{array}{l}P \\
P \\
P \\
P \\
P\end{array}$ & $\begin{array}{l}P \\
P \\
P \\
P \\
P\end{array}$ & $\begin{array}{l}P \\
P \\
P \\
P \\
P\end{array}$ & $\begin{array}{l}P^{\mathrm{i}} \\
\text { BTC }^{\mathrm{i}} \\
\text { BTC }^{\mathrm{j}} \\
\text { BTC }^{\mathrm{j}} \\
\mathrm{P}^{\mathrm{i}}\end{array}$ & $\begin{array}{l}\text { BTC } \\
\text { P } \\
\text { BTC } \\
\text { BTC } \\
\text { BTC }\end{array}$ \\
\hline
\end{tabular}

Notes:"-" (hyphen) = These drugs are not available in those countries, according to sources used for searching actual drug classification. ${ }^{\text {a} T h e s e ~ d r u g s ~ a r e ~ " e x e m p t e d ~}$ dangerous drugs" (EDD, Rx). ${ }^{\text {b}}$ These drugs were classified by the Psychotropic Substances Act B.E. 2559 as psychotropic substances, schedule 2 . A seller must be granted for a license to sell psychotropic substances in schedule 2 and must dispense only when prescriptions are available. "These drugs are granted exemptions for supply without a prescription as BTC drugs if certain criteria are met. ${ }^{d}$ Each brand of these drugs were classified into different categories. ${ }^{e}$ This drug is classified as OPS if it is contained in four or ten tablet-packaging with a designated warning. Otherwise, it is classified as BTC. 'Powder for oral solutions or suspensions. ${ }^{\mathrm{g}}$ This drug was reclassified from "prescription" to "transitional drugs" on 17 January 2017. "This drug is classified as BTC unless it meets certain criteria, which are in divided solid dosage forms for oral use containing 10 milligrams or less per dose with the label "'only for a season allergic rhinitis, not for runny nose from the common cold"” when sold in the manufacturer's original packaging containing not more than 10 tablets per strip, 2 strips per carton. 'In the US, the regulations of vaccines vary among states. The same vaccines in some states may require a prescription, while other states might not require. ${ }^{46}$ ill vaccines in Canada are classified into $\mathrm{SI}$ except those which are part of a routine immunization program in most/all provinces and territories. Reference: concluded in Table 3.

Abbreviations: US, the United States; UK, the United Kingdom; JP, Japan; SG, Singapore; MY, Malaysia; PH, the Philippines; CA, Canada; TH, Thailand; P, prescription drugs; BTC, behind-the-counter drugs; T, transition drugs; OPS, open-shelf drugs; GSL, general sale list drugs; tab, tablets; cap, capsules; loz, lozenges.

Homogeneous drug classification was observed in some drug groups across eight countries. It was found that all countries classify drugs indicated for insomnia (alprazolam, lorazepam, and diazepam), and drugs indicated for nausea and vomiting associated with chemotherapy (ondansetron and granisetron) as prescription drugs. In addition, more than $75 \%$ of our sample countries consistently classify drugs for dyslipidemia, hypertension, diabetes, bacterial infection, and various vaccines as prescription drugs. The classification status of all these drugs as prescription drugs is consistent with drug classification criteria discussed above as they either i) require a disease diagnosis from a healthcare professional, ii) require subsequent disease monitoring from a healthcare professional, iii) can lead to habit formation, iv) contribute to micro-organism resistance, or v) have an injection dosage form.

A diverse drug classification status was found among some drug groups: topical antifungal, non-steroidal antiinflammatory drugs, antihistamines, and drugs used for smoking cessation. Examples of drugs that had a wide range of drug classifications are clotrimazole and ketoconazole cream (prescription, BTC, OPS and GSL drug categories), ibuprofen tablets/capsules (prescription, BTC and GSL), loratadine tablets and cetirizine syrup (prescription, BTC, OPS and GSL), and nicotine patches (prescription, BTC, OPS and GSL).

It was worth noting that among the eight countries, Thailand classified most studied drugs (77.4\%) as BTC drugs. Drugs classified into the prescription drug category in other countries, such as dyslipidemia, hypertension, diabetes, and antibiotics, are classified BTC in Thailand. Conversely, well-established and commonly used drugs like cetirizine tablets, loratadine tablets, and nicotine replacement therapy were classified GSL among countries with higher-incomes and higher rates of education (the US, the UK, Japan, Singapore, and Canada), while these drugs were classified as BTC drugs among middle-income and lesser-educated countries (Malaysia, the Philippines, and Thailand).

\section{Discussion}

This is the first comprehensive study exploring and comparing drug classification systems, drug classification criteria, and how drugs are actually classified across selected countries. The study confirmed that drug classification systems vary across countries, although classification principles are rather consistent. The design of each drug classification system is likely dependent on health professionals' responsibility as the evidence suggests that 
pharmacists' responsibility impacts the specific stipulations of the drug classification system. Countries which have the BTC drug category allow pharmacists to respond to patient's symptoms themselves, while countries that do not allow pharmacists to respond to patient's symptoms independently do not have this drug category.

Drug classification criteria are associated with the drug classification system, health professionals' responsibility, and drug characteristics. Actual drug classification in each country is influenced by multiple factors, such as the drug classification system, different drug classification criteria, individual drug characteristics, the public need, and the public education level. Cetirizine, loratadine, and ibuprofen are examples of drugs that have well-established records of safe use for self-treatment, while nicotine replacement therapies have been found not suitable for selftreatment due to their complicated nature of use (for example, patients need to know the nicotine gums' special chewing technique). Nevertheless, there are many examples of lowering the gatekeeper barrier between the patient and these products to encourage smoking cessation. However, drug regulatory agencies in each country need to evaluate the risk/benefit analysis of these types of therapies within the context of their own country to ensure citizen safety when given access to self-medicate. Thus, it was found that these drugs are less stringently regulated among higher educated countries but are more stringently regulated among lower educated countries.

Drug statuses are not static and can be changed over time. Drug re-classification may result from a drug's safety profile, a health-consciousness trend, or a shift in the professional paradigm. In Thailand, nicotine replacement therapies have been switched from dangerous drugs (BTC drugs) to non-dangerous drugs (OPS drugs) to facilitate access for those who intend to stop smoking. ${ }^{88}$ Likewise in Canada, many vaccines that are prescription products in countries, such as the UK are classified as schedule 2 (BTC drug category), which are under pharmacists' control. This is congruent with the pharmacists' countryspecific role, as certified Canadian community pharmacists are responsible for providing routine immunization to their patients without prescriptions.

As for Thailand, the same four-drug classification system has been implemented for more than five decades. This drug classification system is considered appropriate for Thailand's earlier healthcare system context, wherein type 2 pharmacies were designed to play a prominent role. ${ }^{12}$ In the past, Thailand experienced healthcare professional shortages and inadequate type 1 modern community pharmacies. Moreover, public health insurance was limited only to government officers, their dependents and those working in the private sector. Many Thai citizens had difficulty gaining access to necessary healthcare services and medicines. Type 2 drugstores with trained personnel were one solution to this problem. Type 2 drugstores have been allowed to distribute non-dangerous drugs (OPS drugs) and household remedies (GSL drugs) to communities in order to ensure that people can gain access to drugs easily.

The regulations regarding drug classification have never been amended, even though Thailand's healthcare system has changed tremendously over the past 20 years. Significant improvements in the Thai healthcare system have included the implementation of a universal health insurance system, increasing the pharmacist-to-population ratio, increasing numbers of type 1 community pharmacies, implementing pharmacy accreditation system, enforcing good pharmacy practice, and implementing continuing education for pharmacists and other healthcare professionals along with a professional re-licensing system. ${ }^{5,14}$ At the present, the Ministry of Public Health has ceased issuing type 2 drugstore licensure. ${ }^{10}$ This is because the level of type 1 modern community pharmacies is adequate for the population, thus type 2 drugstores are expected to decrease and eventually become extinct.

Although our findings show that Thailand has similar drug classification criteria as other countries, the actual classification of individual drugs is notably different from other countries, especially for antibiotics, hypertension treatments, and dyslipidemia treatments. These drugs are classified as dangerous drugs (BTC drugs), and by law, they should be a pharmacist's responsibility to dispense. Therefore, if these drugs continue to be in the BTC drug category, pharmacists must have a clear scope of practice when they provide care to patients who use these drugs.

Questions regarding the drug regulatory direction of Thailand were also raised, such as whether the four-drug classification system is still suitable, whether drug classification criteria are still valid, and whether current actual drug classification is still appropriate.

First, how many drug categories does Thailand need? Thailand can choose either a four- or three-drug classification categories (the current system and the new system wherein the OPS drug category will be collapsed into the GSL drug category). This decision should be made by regulators after taking into consideration all relevant medical, economic, and social aspects. If quality of service and 
patient safety are the main focuses for change, a three-drug classification system is preferable. Non-dangerous drugs (OPS drugs) should be subsumed into household remedies (GSL drugs) and type 1 modern community pharmacies will continue to sell BTC drugs. However, if easy access to OPS drugs is still the main focus, as in the past, then a four-drug classification system should continue. It should be noted that if the three-drug classification system is selected immediately, this will affect the viability of existing type 2 drugstores, and thus regulators should implement a fairness policy for these stakeholders before implementing any widespread change.

Second, are the drug classification criteria still valid? Thailand's drug classification criteria are comparable to other countries. However, some actual drug classifications were found to conflict with other countries, especially hypertension treatments, dyslipidemia treatments, diabetes treatments, and antibiotics. It can be concluded that actual drug classification does not conform with the criteria. This is because the drug classification criteria in Thailand were updated for drug re-classification consideration in 2016. Drugs that were previously classified before 2016 were not harmoniously conformed with the updated criteria. ${ }^{11}$ Considering the principles of drug classification criteria; hypertension treatments, dyslipidemia treatments, and diabetes treatments should be classified as prescription drugs since they require physicians' involvement for disease diagnosis and monitoring. For antibiotics, bacterial resistance is one of the most concern issue of this era, and many countries are trying to limit distribution by classifying them as prescription drugs as is shown in Table 6 . Although Canada is the only country that currently uses this as an actual criterion, the comparison of actual drug classification implies that most countries are concerned about this issue. Thus, it is crucial for Thai regulators to consider re-classifying these drugs as prescription drugs.

Although the healthcare system in Thailand has evolved enormously since 2003, many drugs which should require a prescription remain under the BTC drug category. Ignorance concerning the review and management of the drug statuses might result from multiple factors and from various stakeholders, such as pharmaceutical companies, community pharmacies, and physicians. One factor is that drug regulatory agencies do not have enough adverse event reports to support switching from BTC to prescription drug categories. In the past decade, only some drugs were upwardly recategorized based on supporting evidence, for example, anti-tuberculosis drugs were switched from dangerous drugs (BTC drugs) to specially controlled drugs (prescription drugs) because of a demonstrated antibiotic resistance. ${ }^{89}$ This change was well known by healthcare professionals, but not realized by the consumers. However, some changes have had unintended consequences, such as when pseudoephedrine was reclassified from being a psychotropic substance that was nonprescription to being a prescription drug that could only be distributed by hospitals. This resulted in a block to direct access for those having nasal congestion. ${ }^{69}$ Moreover, pharmaceutical companies were asked to replace pseudoephedrine with other drugs in combination preparations for nasal congestion in order to maintain a BTC status. This change has directly affected patients' quality of life, ease of access to common drugs, and healthcare expenditures for many patients who suffer from nasal congestion.

In response to this, a few policy recommendations have been formulated. First, although the drug classification criteria in Thailand are well established, there is concern regarding injections. The current criteria imply that injections can be classified as prescription or BTC drugs. However, since pharmacists in Thailand cannot vaccinate or inject patients, injections should not be under pharmacists' control, or, in other words, cannot be classified into the BTC drug category. Thus, the criteria should specify that injections must be classified only as prescription drugs.

Second, the Thai FDA should re-evaluate drugs listed under the dangerous drug (BTC drug) category to standardize which drugs should be switched to prescription drugs. If the status of these drugs remains unchanged, it is necessary to review the pharmacist's role and responsibility over these drugs. There should be a pharmacy practice guideline, referral guideline, and continuing education that enhances pharmacists' knowledge and skill to care for their patients. There could even be a certified system to ensure that pharmacists as providers are qualified to take care of those drugs.

Third, the general public should be empowered to better understand about association between drug classification and drug access. Prescription drugs must be dispensed in community pharmacies only when prescriptions are presented to the pharmacists. Thai citizens should not need to always visit hospitals for non-prescription drugs since these drugs are available for patients to selfmedicate. It is important to empower Thai citizens by educating them about their responsibility for their own 
health, and to make sure the population understands which situations necessitate visits to hospitals. If their symptoms are minor ailments, they should self-medicate from pharmacies or non-pharmacy retailers first, and avoid excessive hospital visits. Patient information leaflets, labels, advertisements, and other developed digital media may be good options to educate citizens.

Some limitations to these suggestions have been observed. First, classification criteria are amended continuously, and therefore the information gathered in this study may not have captured all these changes. However, we believe that the core principles were captured and that the findings are robust enough to use as supporting evidence. Second, we found that the Philippines' drug database that we used to compare actual drug status was not up to date. Drugs with the same active pharmaceutical ingredient should be in the same category, but various categories were observed. Nonetheless, we interviewed an expert who works in the Food and Drug Administration of the Philippines to confirm the status of these drugs. Third, the drug regulatory authorities of some countries provide information only in their local languages, such as Japan, Malaysia, and the Philippines. Therefore, information searching, gathering and comprehension from these countries was more difficult and required assistance from native speakers. Lastly, since the discussion of this study was based on gathered evidence from documents, several points, such as patients' behavior, were not included in this study. Thus, further focus groups or public hearings from various stakeholders are necessary to conduct before any meaningful implementation.

\section{Conclusion}

In Thailand, drug classification systems should be updated to be more aligned with the country's individual healthcare context, such as healthcare professionals' scope of responsibility. A spotlight should be pointed on drugs intended to be prescription drugs (specially controlled drugs) misclassified as behind the counter drugs (dangerous drugs) as this misclassification could pose a higher risk to the public. Drug regulatory agencies should also educate the general public regarding drug classification systems to empower them to understand when they need to seek care from physicians or when they can practice self-medication.

\section{Acknowledgments}

The Scholarship from the Graduate School, Chulalongkorn University to commemorate the 72nd anniversary of his Majesty King Bhumibol Adulyadej is gratefully acknowledged.

We also would like to extend our appreciation to Assistant Professor Rungpetch Sakulbumringsil, Assistant Professor Suthira Taychakhoonavudh, and Associate Professor Susi Ari Kristina, for their recommendations, which helped to improve this study.

In addition, our sincere thanks also goes to Nattaporn Piensaknusorn and Sirisopa Nakawong, Nantarat Sukrod, Dr Mohd Shahezwan Abd Wahab, Mallenrose Kristine Marcelo Ofrecio, Taichi Hiraga, and Fumiya Seki for providing valuable information and translating several non-English documents. Last, but not least, we would like to thank Stephen Pinder and Laura Saxton for their dedicated English proofreading.

\section{Disclosure}

Noppadon Adjimatera is a committee of the Thailand Self Medication Industry Association and an employee of Reckitt Benckiser (Thailand) Ltd. Lawanworn Broese Van Groenou is an employee of DKSH (Thailand) Limited. The authors report no other potential conflicts of interest in this work.

\section{References}

1. Sukrod N. Principle of Thailand medicine reclassification guidelines; 2015. Available from: http://www.tsmia.or.th/RTD2015/ 5-THAILAND\%20(Sept\%2017)\%20Drug\%20reclassification\% 20guideline\%20(final).pdf. Accessed April 23, 2020.

2. Consumer Healthcare Product Association. Rx-to-OTC switch; 2019. Available from: https://www.chpa.org/switch.aspx. Accessed October 23, 2019.

3. GOV.UK. Oral diclofenac presentations with legal status 'P' - reclassified to POM; 2015. Available from: https://www.gov.uk/drug-devicealerts/drug-alert-oral-diclofenac-presentations-with-legal-status -p-reclassified-to-pom. Accessed Oct 23, 2019.

4. Consumer Healthcare Product Association. Rx-to-OTC switch: switch list; 2018. Available from: https://www.chpa.org/Switch.aspx. Accessed October 26, 2019.

5. World Bank Group President Jim Yong Kim. Speech by World bank group president Jim Yong Kim on universal health coverage in emerging economies; 2014. Available from: https:/www.worldbank.org/en/ news/speech/2014/01/14/speech-world-bank-group-president-jim-yong -kim-health-emerging-economies. Accessed August 2, 2020.

6. Sakulbumrunsul R, Taychakhoonavudh S. Pricing and patient access framework to support universal coverage in Thailand. Available from: http://www.pharm.chula.ac.th/dept5/source/images/data/files/NHSO_ PPA_Report240317(2).pdf. Accessed December 17, 2020.

7. Strategy and planning division: Office of the Permanent Secretary for Ministry of Public Health. Number of hospitals by category in Thailand; 2014. Available from: http://203.157.10.8/hcode_2014/ query_02.php? $\mathrm{p}=3 \% 20 /$. Accessed April 12, 2020.

8. Thai Food and Drug Administration. Number of pharmacies; 2017. Available from: http://www.fda.moph.go.th/sites/drug/Shared\% 20Documents/Statistic/establishment.pdf. Accessed April 23, 2020. 
9. Saramunee K, Chaiyasong S, Krska J. Public health roles for community pharmacy: contrasts and similarities between England and Thailand. Isan J Pharm Sci. 2011;7(2):1-11.

10. Thai Food and Drug Administration. Designation of number of type 2 community pharmacies; 2005. Available from: http://www.ratcha kitcha.soc.go.th/DATA/PDF/2548/00155157.PDF? fbclid= IwAR2Qksp4wyeb5ZnkhGZXUNyigAjknzu92GMReDzdSdIfZGWj d6E32VwRwwE. Accessed April 23, 2020.

11. Thai Food and Drug Administration. Guideline of drug reclassification; 2016. Available from: http://www.fda.moph.go.th/ sites/drug/Shared\%20Documents/reclass/\%E0\%B8\%A0\%E0\%B8\% B2\%Е0\%B8\%84\%Е0\%B8\%9C\%Е0\%B8\%99\%Е0\%B8\%A7\%Е0\% B8\%81\%20\%E0\%B8\%84.pdf. Accessed Oct 23, 2019.

12. The drug act (No. 6) B.E. 2562 (A.D. 2019). Available from: https:// sme.go.th/upload/mod_download/download-20190508065825.PDF. Accessed December 18, 2019.

13. World Health Organization. Thailand pharmaceutical profile; 2017. Available from: https://apps.who.int/iris/bitstream/handle/10665/ 274873/2017-Thailand-pharm-profile.pdf?sequence=1\&isAllowed=y. Accessed April 23, 2020.

14. Chan RC, Ching PL. Pharmacy practice in Thailand. Am J Health Syst Pharm. 2005;62(13):1408-1411. doi:10.2146/ajhp040393

15. Sriviriyanupap W. Developing indicators and method of drug classification according to Thai law. Thai J Pharm Sci. 2016;40.

16. MGR Online. The propose of new drug classification scheme; 2018. Available from: https://mgronline.com/qol/detail/9610000088655. Accessed October 25, 2019

17. Sumpradit N, Chongtrakul P, Anuwong K, et al. Antibiotics smart use: a workable model for promoting the rational use of medicines in Thailand. Bull World Health Organ. 2012;90(12):905-913. doi:10. 2471/BLT.12.105445

18. Bangkok Post. Teens taking 'taxi' ride to drug addiction; 2018. Available from: https://www.bangkokpost.com/thailand/special-reports/1529006/ teens-taking-taxi-ride-to-drug-addiction. Accessed April 23, 2020.

19. Thai Food and Drug Administration. Counterfeit drug manufacturing was found; 2018. Available from: http://pca.fda.moph.go.th/public_media detail.php?id=2\&cat=50\&content_id=1671. Accessed April 25, 2020.

20. Thai Food and Drug Administration. Risks of 4x100 (pro drug); 2020. Available from: https://oryor.com/oryor_miniweb/knowledge_ detail.php?cat=2\&id=7. Accessed April 23, 2020.

21. Thai Food and Drug Administration. Drug database; 2019. Available from: http://pertento.fda.moph.go.th/FDA_SEARCH_DRUG/ SEARCH_DRUG/FRM_SEARCH_DRUG.aspx. Accessed November 4, 2019.

22. GOV.UK. Medicines: reclassify your product; 2019. Available from: https://www.gov.uk/guidance/medicines-reclassify-yourproduct\#classifications-of-medicines. Accessed October 23, 2019.

23. Homhuan A. Amendments to Thailand's drug act; 2019. Available from: https://www.tilleke.com/resources/amendments-thailand $\% \mathrm{E} 2 \%$ 80\%99s-drug-act. Accessed August 2, 2020.

24. Nomura K, Kitagawa Y, Yuda Y, Takano-Ohmuro H. Medicine reclassification processes and regulations for proper use of over-thecounter self-care medicines in Japan. Risk Manag Healthc Policy. 2016;9:173. doi:10.2147/RMHP.S98099

25. Gauld NJ, Kelly FS, Emmerton LM, Buetow SA. Widening consumer access to medicines: a comparison of prescription to non-prescription medicine switch in Australia and New Zealand. PLoS One. 2015;10(3):e0119011. doi:10.1371/journal.pone.0119011

26. Gauld NJ, Kelly FS, Kurosawa N, Bryant LJ, Emmerton LM, Buetow SA. Widening consumer access to medicines through switching medicines to non-prescription: a six country comparison. PLoS One. 2014;9(9):e107726. doi:10.1371/journal.pone.0107726

27. World Health Organization. Proposal for updating the definition of stringent regulatory authority; 2017. Available from: https://www. who.int/medicines/areas/quality_safety/quality_assurance/SRA_ QAS17-728Rev1_31082017.pdf?ua=1. Accessed October 26, 2019.
28. The International Council for Harmonisation of Technical Requirements for Pharmaceuticals for Human Use. Members \& observers; 2019. Available from: https://www.ich.org/page/membersobservers. Accessed October 26, 2019.

29. Association of Southeast Asian Nations. ASEAN member states; 2019. Available from: https://asean.org/asean/asean-member-states/. Accessed December 10, 2019.

30. Filmer D, Rogers H, Angrist N, Sabarwal S. Learning-Adjusted Years of Schooling (LAYS): Defining a New Macro Measure of Education. The World Bank; 2018.

31. Human development index (HDI) by country; 2019. Available from: http://worldpopulationreview.com/countries/hdi-by-country/. Accessed January 12, 2020.

32. United Nations Development Programme. Global human development indicators; 2020. Available from: http://hdr.undp.org/en/coun tries/profiles/. Accessed April 25, 2020.

33. The World Bank. Education Statistics. 2019. Available from: https:// databank. worldbank.org/indicator/UIS.SAP.CE? $\mathrm{id}=\mathrm{c} 755 \mathrm{~d} 342 \& \mathrm{re}$ port_name $=$ EdStats_Indicators_Report\&populartype $=$ series. Accessed January 12, 2020.

34. World Health Organization. Density of physicians. Available from: https://www.who.int/gho/health_workforce/physicians_density/en/. Accessed April 25, 2020.

35. World Health Organization. Pharmacists (per 10,000 populations). Available from: https://www.who.int/data/gho/data/indicators/indica tor-details/GHO/pharmacists-(per-10-000-population). Accessed April 25, 2020

36. Collins S. A tale of two countries: the path to pharmacist prescribing in the United Kingdom and Canada; 2014. Available from: https:// www.pharmacist.com/article/tale-two-countries-path-pharmacistprescribing-united-kingdom-and-canada. Accessed Jan 12, 2020.

37. Deloitte Access Economics. Remuneration and regulation of community pharmacy; 2016. Available from: https://www1.health.gov.au/internet/ main/publishing.nsf/Content/4E0B6EEE19F56A40CA2 581470016D688/\$File/deloitte-community-pharmacy-literature-review -2016.pdf. Accessed January 12, 2020.

38. Nakagawa S, Kume N. Pharmacy practice in Japan. Can J Hosp Pharm. 2017;70(3):232. doi:10.4212/cjhp.v70i3.1663

39. Competency standards for Singapore pharmacists; 2010. Available from: https://www.healthprofessionals.gov.sg/docs/librariesprovider3/ forms-publications/competency-standards-for-singapore-pharmacists -(march-2010).pdf. Accessed November 13, 2020.

40. Chau A. Are pharmacists' roles as primary health professionals underutilised in Singapore? 2016. Available from: https://today. mims.com/are-pharmacists'roles-as-primary-health-professionalsunderutilised-in-singapore-?channel=GN-Local-News-SG. Accessed Jan 12, 2020.

41. General Pharmaceutical Council. What does a pharmacist do? 2019. Available from: https://www.pharmacyregulation.org/raisingconcerns/raising-concerns-about-pharmacy-professional/what-expectyour-pharmacy/what-does-0. Accessed January 12, 2020.

42. Albanese NP, Rouse MJ, Schlaifer M. Pharmacy CoCi. Scope of contemporary pharmacy practice: roles, responsibilities, and functions of pharmacists and pharmacy technicians. J Am Pharm Assoc. 2010;50(2):e35-e69. doi:10.1331/JAPhA.2010.10510

43. Poisons act 1952 and regulations; 2019. Available from: http://www. agc.gov.my/agcportal/uploads/files/Publications/LOM/EN/Act\% 20366\%20online.pdf. Accessed January 12, 2020.

44. Annuar A. Counter-productive' for pharmacists to administer vaccines, doctors' body says; 2019. Available from: https://www.malay mail.com/news/malaysia/2019/02/25/counter-productive-forpharmacists-to-administer-vaccines-doctors-body-says/1726723. Accessed January 12, 2020.

45. Philippine Pharmacy Act. 2015. Available from: https://www.lawphil. net/statutes/repacts/ra2016/ra 10918 2016.html. Accessed Jan 12, 2020. 
46. International Pharmaceutical Federation. An overview of current pharmacy impact on immunisation; 2016. Available from: https:// www.fip.org/www/streamfile.php?filename=fip/publications/FIP report_on_Immunisation.pdf. Accessed Jan 12, 2020.

47. Pharmaceutical Profession Act (No.2). 2015. Available from: https:// library2.parliament.go.th/giventake/content_nla2557/law21-26035869.pdf. Accessed Jan 12, 2020.

48. U.S. Food and Drug Administration. Prescription drug advertising; 2019. Available from: https://www.fda.gov/drugs/drug-informationconsumers/prescription-drug-advertising. Accessed April 25, 2020.

49. GOV.UK. Advertise your medicines; 2020. Available from: https:// www.gov.uk/guidance/advertise-your-medicines\#advertise-to-thepublic. Accessed April 25, 2020.

50. Graham JS, Swanson R. Distribution and marketing of drugs in Canada: overview; 2018. Available from: https://ca.practicallaw.thom sonreuters.com/0-618-6695? transitionType=Default\&contextData= (sc.Default)\&firstPage=true\&bhcp=1. Accessed April 25, 2020.

51. Government of Canada. Health products advertising on physician web sites - questions and answers; 2011. Available from: https://www.canada. ca/en/health-canada/services/drugs-health-products/regulatoryrequirements-advertising/policies-guidance-documents/health-productsadvertising-physician-questions-answers.html. Accessed April 25, 2020.

52. Health Sciences Authority. Advertisements and promotions of therapeutic products; 2019. Available from: https://www.hsa.gov.sg/ther apeutic-products/advertisements. Accessed April 25, 2020.

53. The international comparative legal guide to: pharmaceutical advertising; 2016. Available from: https://www.jurists.co.jp/sites/ default/files/tractate_pdf/en/PA16_Japan.pdf. Accessed April 25, 2020.

54. Thai Food and Drug Administration. Things to know for drug advertisements; 2020. Available from: http:/www.fda.moph.go.th/ sites/drug/SitePages/advertisement03.aspx. Accessed April 25, 2020.

55. Baker M. Promoting medical products globally; 2018. Available from: https://www.bakermckenzie.com/-/media/files/insight/publica tions/2018/03/healthcare/ap/promoting-medical-productsglobally_malaysia.pdf?la=en. Accessed April 25, 2020.

56. The ministry of health in collaboration with the World Health Organization. Philippines pharmaceutical country profile; 2011. Available from: https:/www.who.int/medicines/areas/coordination/ Philippines_PSCPBNarrativeQuestionnaireEndorsement_13062012. pdf?ua=1. Accessed April 25, 2020.

57. The food, drug, and cosmetic act, code of federal regulations. 2019.

58. Medicines act 1968. 2020.

59. Japan Pharmaceutical Manufacturers Association. Pharmaceutical administration and regulations in Japan; 2019. Available from: http://www.jpma.or.jp/english/parj/pdf/2019.pdf. Accessed January 12, 2020.

60. Health Products Act. 2016. Available from: https://sso.agc.gov.sg/SL/ HPA2007-S329-2016. Accessed Jan 12, 2020.

61. National Association of Pharmacy Regulatory Authorities. Drug scheduling in Canada - general overview; 2019. Available from: https://napra.ca/drug-scheduling-canada-general-overview. Accessed December 10, 2019.

62. U.S. Food and Drug Administration. How to buy medicines safely from an online pharmacy; 2018. Available from: https://www.fda. gov/consumers/consumer-updates/how-buy-medicines-safely-onlinepharmacy. Accessed April 25, 2020.

63. GOV.UK. Register for the distance selling logo; 2017. Available from: https:/www.gov.uk/guidance/register-for-the-distance-sellinglogo. Accessed April 25, 2020.

64. Ministry of Health Malaysia. Tips on how to buy medicines online; 2020. Available from: https://www.pharmacy.gov.my/v2/en/content/ tips-how-buy-medicines-online.html. Accessed April 25, 2020.

65. Government of Canada. Choosing a safe online pharmacy; 2020 Available from: https:/www.canada.ca/en/health-canada/topics/buy ing-using-drug-health-products-safely/safe-use-online-pharmacies. html. Accessed April 25, 2020.
66. Faculty of Medicine Ramathibodi Hospital. Online drug sale; 2018. Available from: https://med.mahidol.ac.th/ramapharmacy/th/knowl edge/general/05192016-1800-th. Accessed February 20, 2020.

67. Health Sciences Authority. Explanation note for application of a pharmacy licence; 2016. Available from: https://www.hsa.gov.sg/ docs/default-source/hprg-ald/phl_explanationnoteb201f748dd3a4a8ca9bd36f432a3fded.pdf. Accessed April 25, 2020.

68. Consumer Healthcare Product Association. FAQs about drug distribution in the United States; 2019. Available from: https://www.chpa. org/FAQDrugDistribution.aspx. Accessed October 23, 2019.

69. U.S. Food and Drug Administration. Legal requirements for the sale and purchase of drug products containing pseudoephedrine, ephedrine, and phenylpropanolamine; 2017. Available from: https:// www.fda.gov/drugs/information-drug-class/legal-requirements-saleand-purchase-drug-products-containing-pseudoephedrine-ephedrineand. Accessed January 12, 2020.

70. National Association of Pharmacy Regulatory Authorities. Implementation of the national drug schedules; 2019. Available from: https://napra.ca/implementation-national-drug-schedules. Accessed January 12, 2020.

71. Comprehensive Dangerous Drugs Act. 2002. Available from: https:// www.ddb.gov.ph/images/Board_Regulation/2014/BD.REG1.14.pdf. Accessed Jan 12, 2020.

72. Gauld N, Bryant L, Emmerton L, Kelly F, Kurosawa N, Buetow S. Why does increasing public access to medicines differ between countries? Qualitative comparison of nine countries. J Health Serv Res Policy. 2015;20(4):231-239. doi:10.1177/1355819615593302

73. Hennebry S. When a 20 year patent term just isn't enough: market and data exclusivity; 2018. Available from: https://fpapatents.com/ resource?id=483. Accessed April 25, 2020.

74. Medicines and Healthcare products Regulatory Agency. How to change the legal classification of a medicine in the UK; 2006. Available from: https://assets.publishing.service.gov.uk/government/ uploads/system/uploads/attachment_data/file/277307/Legal_classifica tion_changes.pdf. Accessed April 25, 2020.

75. Agency for Care Effectiveness. Drug evaluation methods and process guide; 2018. Available from: http://www.ace-hta.gov.sg/public-data /our-process-and-methods/ACE $\% 20$ methods $\% 20$ and $\% 20$ process $\%$ 20guide\%20for\%20drug\%20evaluation\%20(5\%20Feb\%202018).pdf. Accessed April 25, 2020.

76. Gauld NJ. How and Why Do Developed Countries Vary in Reclassifying Medicines from Prescription to Non-Prescription? University of Auckland; 2013.

77. Camargo. Rx-to-OTC switch: expanding to the US over-the-counter market; 2017. Available from: https://camargopharma.com/resources/ blog/rx-to-otc-switch-expanding-to-the-us-over-the-counter-market. Accessed April 25, 2020.

78. Mithun Raja. B, Raghavendra Rao. K. Regulatory and clinical requirements for prescription to OTC switches in USA and India; 2013. Available from: https://www.complianceonline.com/articlefiles/ Regulatory_Requirements_Prescription_to_OTC_Switches_USA_ India.pdf. Accessed Jan 12, 2020.

79. U.S. Food and Drug Administration. Bringing an over-the-counter (OTC) drugs to market; 2020. Available from: https://www.access data.fda.gov/scripts/cder/training/OTC/topic2/topic2/da_01_02_ 0080.htm. Accessed April 25, 2020.

80. Health Sciences Authority. Therapeutic products guidance; 2019. Available from: https://www.hsa.gov.sg/docs/default-source/hprg/thera peutic-products/guidance-documents/guidance-on-therapeutic-productregistration-in-singapore_jan2019.pdf. Accessed April 25, 2020.

81. Tago S, Ueda A, Kudo R, Guesdon L. Distribution and marketing of drugs in Japan: overview; 2019. Available from: https://uk.practical law.thomsonreuters.com/5-618-3562?transition Type $=$ Default $\&$ contextData $=($ sc. Default $) \&$ firstPage $=$ true $\&$ comp $=$ pluk\&bhcp=1. Accessed April 25, 2020. 
82. National Association of Pharmacy Regulatory Authorities. National drug scheduling factors; 2017. Available from: https://napra.ca/sites/ default/files/documents/NDSAC_Scheduling_Factors_website_ September2017.pdf. Accessed January 12, 2020.

83. Katsura H. The approval standards for OTC drugs in Japan; 2015. Available from: http:/www.tsmia.or.th/RTD2015/2-Japan $\% 202 \mathrm{nd} \%$ 20self-CARER\%20(PMDA\%20Ehidemi\%20Katsura).pdf. Accessed January 17, 2020.

84. Bakah SA. Regulation of OTC medicines in Malaysia; 2017. Available from: https://www.tga.gov.au/sites/default/files/interna tional-over-counter-otc-medicines-regulators-forum-2017-malaysia. pdf. Accessed November 13, 2020.

85. Official Portal of Pharmaceutical Services Programme, Ministry of Health Malaysia. Application for poisons classification guideline under the poisons act 1952; 2013. Available from: https://www.phar macy.gov.my/v2/sites/default/files/document-upload/garispanduan. pdf. Accessed Jan 12, 2020.

86. Policies and guidelines on over-the-counter (OTC) drug products; 2000. Available from: https://ww2.fda.gov.ph/attachments/article/ 16557/ao\%2023c\%202000.pdf. Accessed Jan 12, 2020.
87. Republic of the Philippines DoH, Food and Drug Administration. Application process and requirements for post-approval changes of pharmaceutical products; 2014. Available from: https://ww2.fda.gov. ph/attachments/article/148395/FC2014-008\%20-\%20Application\% 20Process $\% 20$ and $\% 20$ Requirments $\% 20$ for $\% 20$ Post-Approval\% 20Changes $\% 20$ of $\% 20$ Pharmaceutical\%20Products.pdf. Accessed April 25, 2020.

88. Ministry of Public Health. 30th notification of dangerous drugs; 2018. Available from: http://www.fda.moph.go.th/sites/drug/Shared \%20Documents/Law03-TheMinistryOfHealth/Dangerousdrugs(30). PDF. Accessed August 2, 2020.

89. Ministry of Public Health. 53th notification of specially controlled drugs; 2019. Available from: http://www.fda.moph.go.th/sites/drug/ Shared\%20Documents/Law03-TheMinistryOfHealth/SPC(53).pdf. Accessed August 2, 2020.
Risk Management and Healthcare Policy

\section{Publish your work in this journal}

Risk Management and Healthcare Policy is an international, peerreviewed, open access journal focusing on all aspects of public health, policy, and preventative measures to promote good health and improve morbidity and mortality in the population. The journal welcomes submitted papers covering original research, basic science, clinical \& epidemiological studies, reviews and evaluations,
Dovepress

guidelines, expert opinion and commentary, case reports and extended reports. The manuscript management system is completely online and includes a very quick and fair peer-review system, which is all easy to use. Visit http://www.dovepress.com/testimonials.php to read real quotes from published authors. 